\title{
Mikroplan zagospodarowania przestrzennego - analiza wybranych zagadnień
}

\begin{abstract}
Wstęp
$\mathrm{Na}$ przestrzeni ostatnich lat można zaobserwować nowe zjawisko w zakresie działalności planistycznej gmin, polegające na wzrastającej tendencji do uchwalania tzw. mikroplanów zagospodarowania przestrzennego. Są to miejscowe plany zagospodarowania przestrzennego ${ }^{1}$, charakteryzujące się tym, że obejmują obszar o niewielkiej powierzchni, składający się najwyżej z kilku działek ewidencyjnych. Pojęcie mikroplanu nie jest pojęciem języka prawnego ani prawniczego - zostało ukształtowane w celu uwypuklenia cech wyróżniających ten rodzaj działalności planistycznej². W szczególnym nasileniu takie działania planistyczne występują w Warszawie i w Poznaniu. Przykładowo, osobne miejscowe plany dotyczą (mają dotyczyć) obszarów o powierzchniach:

- $388 \mathrm{~m}^{2}$ - jest to obszar składający się z dwóch działek ewidencyjnych³,

- $188 \mathrm{~m}^{2}$ - jest to obszar składający się z jednej działki ewidencyjnej4,

- $479 \mathrm{~m}^{2}$ - jest to obszar również składający się z jednej działki ewidencyjnej',
\end{abstract}

$1 \mathrm{~W}$ dalszej części będę posługiwać się określeniem „plan miejscowy”, natomiast w odniesieniu do mikroplanu zagospodarowania przestrzennego - określeniem „mikroplan”.

2 V. K. Wardacki, Skarga na mikroplany, „Rzeczpospolita” z dnia 28.11.2014 r., nr 276.

3 Uchwała nr XV/123/VII/2015 Rady Miasta Poznania z dnia 14 lipca 2015 r. w sprawie przystąpienia do sporządzenia miejscowego planu zagospodarowania przestrzennego „Paderewskiego - Szkolna” w Poznaniu, dostępna na stronie internetowej www.bip.poznan.pl [dostęp: 6.03.2016].

4 Uchwała nr LVI/862/VI/2013 Rady Miasta Poznania z dnia 24 września 2013 r. w sprawie miejscowego planu zagospodarowania przestrzennego „U zbiegu placu Wiosny Ludów i ulicy Podgórnej” w Poznaniu, Dz.Urz. Województwa Wielkopolskiego 2013 poz. 5902.

5 Uchwała nr LVIII/602/IV/2004 Rady Miasta Poznania z dnia 7 grudnia 2004 r. w sprawie uchwalenia miejscowego planu zagospodarowania przestrzennego „Naramowice - ul. Czarnucha”- część południowa A, Dz.Urz. Województwa Wielkopolskiego 2005 nr 25 poz. 638. 
- ok. $120 \mathrm{~m}^{2}$ - jest to obszar obejmujący podwórko sąsiadujące z budynkami wielorodzinnymi ${ }^{6}$.

Należy zaznaczyć, że powyższe dane mają na celu jedynie zobrazowanie istoty zjawiska polegającego na przyjmowaniu mikroplanów. Jednocześnie warto mieć na uwadze, że takie działania planistyczne często wiążą się z podjęciem próby rozwiązania aktualnych problemów, wynikających ze struktury własnościowej czy obecnego zagospodarowania terenu? ${ }^{7}$.

Przedmiotem niniejszego artykułu jest zbadanie dopuszczalności takiej działalności planistycznej gmin w świetle wymagań stawianych przez normy składające się na polski system planowania przestrzennego - zarówno tych wymagań, które zostały wyrażone wprost przez ustawodawcę w przepisach ustawy z dnia 27 marca 2003 r. o planowaniu i zagospodarowaniu przestrzennym ${ }^{8}$ (dalej u.p.z.p.), jak i tych, które są rekonstruowane na podstawie przepisów ogólnych ww. ustawy. Rozważania obejmą także analizę charakteru prawnego mikroplanów w kontekście założeń teoretycznych dotyczących planu miejscowego, jak też stanowisko sądów administracyjnych odnośnie do dopuszczalności przyjmowania mikroplanów ${ }^{9}$.

\section{Mikroplan wobec poglądów na charakter prawny planu miejscowego}

W pierwszej kolejności warto zastanowić się, czy mikroplan odpowiada specyficznym cechom konstrukcyjnym, charakterystycznym dla planu miejscowego. Ustawodawca nadaje bowiem planowi miejscowemu rangę aktu prawa miejscowego - plan miejscowy stanowi więc źródło powszechnie obowiązującego prawa (art. 14 ust. 8 u.p.z.p.). Niemniej plan miejscowy zawiera nietypowe normy, których charakter - również w kontekście planów gospodarczych - był przedmiotem wielu sporów w nauce prawa ${ }^{10}$. Najistotniejszy spór dotyczył kwestii, czy plan miejscowy stanowi akt normatywny per se, tzn.

6 Uchwała nr XVIII/405/2015 Rady Miasta Stołecznego Warszawy z dnia 15 października 2015 r. w sprawie przystąpienia do sporządzenia miejscowego planu zagospodarowania przestrzennego dla działki ew. nr 2/2 z obrębu 1-05-53, www.architektura.um.warszawa.pl [dostęp: 6.03.2016].

7 Dla przykładu, przyjmowanie mikroplanów dla obszarów położonych w Warszawie często jest powiązane z problematyką reprywatyzacji gruntów, znacjonalizowanych na podstawie dekretu z dnia 26 października 1945 r. o własności i użytkowaniu gruntów na obszarze m.st. Warszawy (Dz.U. nr 50 poz. 279 z późn. zm.).

8 t.j. Dz. U. 2016, poz. 778 z późn. zm.

9 Celem niniejszego artykułu nie jest badanie przyczyn takiej działalności gmin.

10 W. Brzeziński, Plan zagospodarowania przestrzennego. Studium z zakresu nauki administracji i prawa administracyjnego, Warszawa 1961, s. 24 i n.; F. Longchamps, O pojęciu stosunku administracyjnoprawnego w gospodarce narodowej, „Państwo i Prawo” 1958, nr 1, s. 14 i n.; M. Kulesza, Administracyjnoprawne uwarunkowania polityki przestrzennej, Warszawa 1987, s. 143 i n.; 
ze względu na normy w nim zawarte, czy też stanowi akt normatywny jedynie na mocy decyzji ustawodawcy ${ }^{11}$.

Nie rozstrzygając w tym opracowaniu sporu o normatywny charakter planu miejscowego, warto odnieść dwie główne koncepcje, sformułowane na kanwie tegoż sporu, do zjawiska mikroplanów w celu znalezienia odpowiedzi na pytanie, czy przyjęcie takiego specyficznego planu miejscowego koresponduje z założeniami teoretycznymi.

Według Z. Niewiadomskiego plan miejscowy zawiera $z$ jednej strony elementy klasycznego aktu normatywnego (przede wszystkim ze względu na to, że z woli ustawodawcy plan miejscowy stanowi akt prawa miejscowego), a z drugiej - aktu indywidualnego, gdyż zdaje się regulować sytuację prawną właścicieli poszczególnych nieruchomości objętych danym planem ${ }^{12}$. To „rozwarstwienie” pozwoliło Z. Niewiadomskiemu na sformułowanie koncepcji, według której plan miejscowy stanowi w istocie „akt indywidualny wielokrotnego stosowania”, umiejscowiony pomiędzy aktem stanowiącym a stosującym prawo $^{13}$. W jego ocenie pogląd ten znajduje również uzasadnienie w ustawowej relacji pomiędzy planem miejscowym a decyzją o warunkach zabudowy - plan miejscowy stanowi bardzo specyficzny akt stosowania prawa, ponieważ po jego uchwaleniu nie jest konieczne wydanie decyzji o warunkach zabudowy (art. 4 ust. 2 u.p.z.p.), gdyż odpowiednie normy zawarte są w planie ${ }^{14}$. Natomiast wprowadzenie art. 14 ust. 8 u.p.z.p., na mocy którego plan miejscowy z woli ustawodawcy stanowi akt prawa miejscowego, oznacza, że „ustawodawca dozwala i zobowiązuje właściwe organy samorządu terytorialnego stanowiące plan zagospodarowania przestrzennego do tego, aby wypowiedzi planu miały charakter powszechnie obowiązujący, oczywiście nie w całości i niekoniecznie muszą to być normy prawne w klasycznej postaci”15.

Wydaje się, że za tym poglądem podążył Trybunał Konstytucyjny, który w jednym z postanowień stwierdził, że „miejscowe plany zagospodarowania przestrzennego są [...] aktami o szczególnym charakterze. Mieszczą się one między klasycznymi aktami normatywnymi a klasycznymi aktami indywidualnymi związanymi ze stosowaniem pra-

R. Malinowski, Ewolucja systemu planowania gospodarczego a problem charakteru prawnego planów gospodarczych, „Państwo i Prawo” 1975, nr 2, s. 37 i n.

11 Zasadniczo normatywny charakter normom planowym - a tym samym planom miejscowym - przyznał W. Brzeziński (op. cit.). Przeciwko takiej koncepcji opowiedzieli się m.in. F. Longchamps (op. cit.) i M. Kulesza (op. cit.). Obecnie Z. Niewiadomski postuluje - idąc częściowo za poglądem W. Brzezińskiego - przyznanie danemu planowi miejscowemu charakteru aktu normatywnego dopiero po jego przebadaniu (ad casum): Z. Niewiadomski, Planowanie przestrzenne. Zarys systemu, Warszawa 2003, s. 109; z kolei za normatywnym charakterem planów miejscowych zdecydowanie opowiada się M. Szewczyk, [w:] Z. Leoński, M. Szewczyk, M. Kruś, Prawo zagospodarowania przestrzeni, Warszawa 2012, s. 83.

12 Z. Niewiadomski, op. cit., s. 110.

13 Ibidem.

14 Ibidem, s. 109.

15 Ibidem. 
wa" ${ }^{16}$. Trybunał skonstatował, że plan miejscowy jest aktem „wielostronnym” (na skutek np. podziału nieruchomości) i „wielokrotnym” (na skutek np. zmian właścicieli danej nieruchomości), a więc regulującym prawo własności także na przyszłość, tj. w odniesieniu do osób, które w przyszłości będą właścicielami nieruchomości objętych planem, również po ich ewentualnym podziale. W tym ujęciu plan miejscowy jawi się jako akt stosowania prawa, o cechach aktu normatywnego.

Odnosząc powyższe uwagi do mikroplanu, prima facie wydaje się, że skoro mikroplan kształtuje sytuację prawną tylko jednego właściciela nieruchomości (czy też niewielkiej liczby właścicieli nieruchomości), to w tym przypadku następuje szczególne nasilenie cech charakterystycznych dla aktu stosowania prawa. Niemniej należy zauważyć, że czynniki wyróżniające mikroplan, tj. niewielki obszar czy ograniczony krąg podmiotów, których sytuację prawną reguluje, nie niwelują tych aspektów, które w ocenie Z. Niewiadomskiego przybliżają plan miejscowy do aktu normatywnego, tj. „wielokrotnej stosowalności”, czy też - w ujęciu Trybunału Konstytucyjnego - „wielostronności” i „wielokrotności”. Mikroplan, pomimo swoich cech specyficznych, nadal wykazuje „wielokrotną stosowalność"; na jego byt prawny nie mają bowiem wpływu takie zdarzenia prawne, jak przeniesienie prawa własności nieruchomości czy jej podział. W dalszym ciągu, pomimo zmian podmiotowych, będzie on kształtował sytuację prawną każdego właściciela nieruchomości. Przedmiotem jego regulacji nadal jest „Ustalenie przeznaczenia terenu, rozmieszczenie inwestycji celu publicznego oraz określenie sposobów zagospodarowania i warunków zabudowy terenu [...]" (art. 4 ust. 1 u.p.z.p.), a nie - bezpośrednio - kształtowanie sytuacji prawnej adresata, jak w przypadku indywidualnego aktu stosowania prawa. Tych specyficznych cech, tj. „wielostronności” i „wielokrotności”, pozbawiona jest decyzja o warunkach zabudowy. Przykładowo, w tym przypadku, jak wskazują przepisy u.p.z.p., sam fakt nabycia nieruchomości od podmiotu uprawnionego z tytułu decyzji o warunkach zabudowy nie powoduje zmiany podmiotu uprawnionego. Aby osiągnąć ten skutek, konieczne jest bowiem przeniesienie jej na podstawie decyzji wydanej przez organ po przeprowadzeniu postępowania administracyjnego (art. 63 ust. 5 u.p.z.p.). Na powyższą konstatację nie wpływa to, że organ, który wydał decyzję, jest zobowiązany do jej przeniesienia, pod warunkiem spełnienia określonych warunków, na rzecz innej osoby. Czynniki wyróżniające mikroplan nie pozbawiają go również charakteru aktu prawa miejscowego - zgodnie z wolą ustawodawcy każdy plan miejscowy stanowi takiż akt normatywny (art. 14 ust. 8 u.p.z.p.). Prawodawca nie wprowadził w tym zakresie różnic pomiędzy poszczególnymi planami miejscowymi. $Z$ tego względu, nawet w sytuacji gdy mikroplan obejmuje jedną, niewielką działkę, pozostaje on aktem prawa miejscowego. Biorąc to pod uwagę, uzasadnione wydaje się stwierdzenie, że mikroplan, pomimo swo-

16 Postanowienie TK z dnia 6 października 2004 r., sygn. akt SK 42/02, Legalis nr 65689. Postanowieniem tym Trybunał orzekł, że do badania konstytucyjności planów miejscowych uprawnione są co do zasady sądy administracyjne. 
ich specyficznych cech, w pełni koresponduje z koncepcją planu miejscowego jako indywidualnego aktu wielokrotnego stosowania, przedstawioną przez Z. Niewiadomskiego.

Ponadto warto zbadać spójność mikroplanu z inną koncepcją dotyczącą charakteru prawnego planu miejscowego, skonstruowana przez M. Szewczyka. Autor ten zdaje się nie akceptować poglądu, że plan miejscowy stanowi akt wielokrotnego stosowania. Stwierdza bowiem, że plan miejscowy stanowi akt normatywny ze względu na to, że powinien „zawierać określenie przeznaczenia terenów” ${ }^{17}$. Idąc dalej, w ocenie M. Szewczyka:

[...] wskazuje się [za pomocą planu miejscowego - D.I.] potencjalnie każdemu zachowanie określone abstrakcyjnie co do możliwości dokonywania zagospodarowania tego obszaru, a nie - jak twierdzi Z. Niewiadomski - konkretnych nieruchomości. Bez wątpienia bowiem plan miejscowy nie dotyczy żadnych konkretnych nieruchomości, lecz obowiązuje na obszarze o ściśle określonych granicach. [...] Określone w planie miejscowym przeznaczenie jakiegoś obszaru będzie następnie stanowić wzorzec zachowań zarówno dla organów władzy publicznej [...], jak i dla obywateli i dla innych podmiotów zrównanych z nimi w zakresie przestrzegania prawa (np. w związku z wykonywaniem uprawnień właścicielskich względem nieruchomości) ${ }^{18}$.

Zgodnie z powyższym poglądem punktem odniesienia dla planu miejscowego, w zakresie jego regulacji, jest zawsze dany teren, a nie konkretna nieruchomość czy też ich określony zbiór. Autor ten zwraca ponadto uwagę, że w odniesieniu do planów miejscowych konieczne jest zastosowanie specyficznej metody dekodowania norm prawnych w nich zawartych:

W planie miejscowym najczęściej zamieszczane są te fragmenty norm prawnych, które tradycyjnie określane są mianem hipotez. Skorelowane z nimi dyspozycje często można znaleźć w ustawach, w szczególności w ustawie o planowaniu i zagospodarowaniu przestrzeni ${ }^{19}$.

$Z$ tego względu rekonstrukcja norm prawnych zawartych w planie miejscowym jest możliwa, jeżeli zestawi się je z określonym przepisem ustawy; dzięki takiemu zrekonstruowaniu normy zawartej w planie miejscowym - normy generalnej i abstrakcyjnej - może ona stanowić podstawę wydania aktów stosowania prawa ${ }^{20}$. W ocenie M. Szewczyka argument ten przemawia na rzecz normatywnego charakteru planu miejscowego

17 M. Szewczyk, op. cit., s. 83.

18 Ibidem.

19 Ibidem, s. 120.

20 Ibidem. 
(przynajmniej w części) ${ }^{21}$. M. Szewczyk zdaje się prezentować pogląd, według którego plan miejscowy - jako akt, którego normy mogą być odczytywane tylko w zestawieniu z normami zawartymi w ustawach - nie jest aktem indywidualnym wielokrotnego stosowania, ale aktem normatywnym, o tyle nietypowym, że dla jego odczytania konieczne jest sięgnięcie do innych aktów prawnych, rangi ustawowej. Stąd w jego ocenie wyżej omawiana „wielokrotna stosowalność” jest jedynie iluzoryczna, ponieważ w istocie plan miejscowy jest aktem normatywnym, który znajdzie zastosowanie do szerszego, bliżej nieokreślonego kręgu podmiotów. Można z tego również wyciągnąć wniosek, że plan miejscowy nie może być traktowany jako zbiór indywidualnych regulacji, określających przeznaczenie konkretnych nieruchomości. Koresponduje to z obserwacją autora co do rzeczywistego przedmiotu regulacji planu miejscowego - w jego ocenie plan miejscowy nie dotyczy konkretnych nieruchomości, ale obszaru składającego się z danych nieruchomości ${ }^{22}$.

Pierwsza z przytoczonych tez M. Szewczyka, dotycząca rzeczywistego przedmiotu regulacji miejscowego planu, znajduje zastosowanie również w przypadku mikroplanu. Trudno dostrzec argumenty, które przemawiałaby przeciwko stwierdzeniu, że mikroplan wskazuje określone zachowanie poprzez sposób zagospodarowania danego obszaru, a irrelewantne pozostaje, kto indywidualnie jest tym wskazaniem związany. Tak jak w typowym planie miejscowym, przedmiotem regulacji jest bowiem sposób zagospodarowania określonej przestrzeni. Nie jest tu zatem istotne, że obszar ten jest niewielki bądź że stanowi własność niewielkiej liczby podmiotów. Nie jest też wykluczone odmienne stwierdzenie, polegające na tym, że w istocie mikroplan jest narzędziem służącym gminie do uregulowania sposobu zagospodarowania danej nieruchomości, a nie oznaczonego granicami obszaru. Konstatacja ta wskazywałaby, że mikroplan nie koresponduje w pełni z założeniami teoretycznymi dotyczącymi charakteru prawnego planu miejscowego. $\mathrm{W}$ mojej ocenie takie spojrzenie - z perspektywy teoretycznej konstrukcji planu miejscowego - nie jest w pełni trafne. Podobna prawidłowość wystąpi bowiem w przypadku, gdy w planie miejscowym przyjętym dla dużego obszaru przyjęto odmienny sposób zagospodarowania dla sąsiadujących ze sobą nieruchomości. Wówczas także możliwe jest stwierdzenie, że plan miejscowy służy do uregulowania statusu prawnego konkretnej nieruchomości, a nie obszaru. Nie można również abstrahować od tego, że często najbardziej wskazanym kierunkiem określenia granic obszarów obejmowanych danym planem miejscowym, jak i odmiennym sposobem zagospodarowania jest uwzględnienie granic poszczególnych działek. Mikroplan, pomimo swoich specyficznych cech, w pełni wpisuje się w aspekty konstrukcyjne właściwe dla każdego planu miejscowego. Co więcej, również w odniesieniu do mikroplanu, dla rekonstrukcji norm w nim zawartych, konieczne jest sięgnięcie do norm ujętych w aktach prawnych rangi ustawowej - schemat dekodo- 
wania norm prawnych zawartych w mikroplanie nie różni się od schematu właściwego dla planów miejscowych. W konsekwencji treść norm zawartych w mikroplanie nie wykazuje odrębności względem treści norm zawartych w innych planach miejscowych.

Powyższe rozważania pozwalają stwierdzić, że niezależnie od przyjętego poglądu na charakter prawny planu miejscowego mikroplan koresponduje z założeniami teoretycznymi przedstawionymi przez Z. Niewiadomskiego i M. Szewczyka. Sugerowałoby to, że czynniki decydujące o specyfice mikroplanu, tj. niewielki obszar oraz krąg podmiotów, których dotyczy mikroplan, przynajmniej z tej perspektywy, są irrelewantne dla konstrukcji prawnej planu miejscowego $-\mathrm{z}$ tego powodu powinny być traktowane raczej jako okoliczności faktyczne, nieodgrywające roli w zakresie oceny teoretycznych założeń dotyczących planu miejscowego.

\section{Mikroplan wobec przepisów u.p.z.p.}

Niezbędne jest też zadanie pytania, czy u.p.z.p. zawiera przepisy wprost regulujące dopuszczalną wielkość obszaru, który może zostać objęty planem miejscowym. Przede wszystkim należy wskazać, że ustawodawca powierzył kształtowanie i prowadzenie polityki przestrzennej na terenie gminy, w tym poprzez uchwalanie miejscowych planów, gminie w ramach jej zadań własnych (art. 3 ust. 1 u.p.z.p.). Przepis ten stanowi ustawową podstawę kompetencji gminy w zakresie uchwalania miejscowych planów, która $z$ kolei wchodzi w zakres władztwa planistycznego gminy. Jednocześnie ustawodawca wprowadził w treści u.p.z.p. reguły dotyczące opracowania planów miejscowych. Po pierwsze, sprecyzował rolę planu miejscowego, stanowiąc, że „Ustalenie przeznaczenia terenu, rozmieszczenie inwestycji celu publicznego oraz określenie sposobów zagospodarowania i warunków zabudowy terenu następuje w miejscowym planie zagospodarowania przestrzennego” (art. 4 ust. 1 u.p.z.p.). W tymże przepisie „została ustalona zasada określająca, jakim celom zgodnie $z$ wolą ustawodawcy ma służyć miejscowy plan zagospodarowania przestrzennego" ${ }^{23}$. Ustawowa rola miejscowego planu znajduje odzwierciedlenie w kolejnych przepisach, np. w art. 14 ust. 1 u.p.z.p., który stanowi o rozpoczęciu prac od podjęcia uchwały o przystąpieniu do sporządzenia miejscowego planu „w celu ustalenia przeznaczenia terenów”. Natomiast w kolejnej, istotnie sformalizowanej fazie przygotowania planu miejscowego konieczne jest określenie przeznaczenia terenów oraz linii rozgraniczającej tereny o różnym przeznaczeniu lub różnych zasadach zagospodarowania, a składnik ten powinien znaleźć się w ostatecznej wersji planu miejscowego (art. 15 ust. 2 pkt 1 u.p.z.p.). Przepisy powyższej ustawy konsekwentnie operują więc w odniesieniu do miejscowego planu pojęciem „terenu” lub „terenów”.

23 A. Plucińska-Filipowicz, T. Filipowicz, Komentarz do art. 4, w: Ustawa o planowaniu i zagospodarowaniu przestrzennym. Komentarz, red. A. Plucińska-Filipowicz, M. Wierzbowski, LEX/el. 2014, Nb. 1. 
Pojęcie „terenu” nie zostało zdefiniowane przez ustawodawcę, a per se nie zawiera odniesień do wielkości obszaru. Może więc zostać użyte zarówno w odniesieniu do planu miejscowego obejmującego znaczny obszar, jak i mikroplanu. Ponadto w zakresie terminologii, z której korzysta ustawodawca, pomocne może okazać się sięgnięcie do konkurencyjnego narzędzia kształtowania polityki przestrzennej, tj. decyzji o warunkach zabudowy. I tak, „W przypadku braku planu miejscowego, dla inwestycji innej niż inwestycja celu publicznego, sposób zagospodarowania terenu i warunki zabudowy ustala się w drodze decyzji o warunkach zabudowy [...]" (art. 4 ust. 2 pkt 2 u.p.z.p.). Przepis wprowadzający rozróżnienie między poszczególnymi aktami planistycznymi posługuje się więc jednakowym terminem „terenu” - zarówno w odniesieniu do planu miejscowego, jak i decyzji o warunkach zabudowy. Dalsze przepisy odnoszące się do powyższej decyzji również zawierają termin „teren”. Wydaje się więc, że ustawodawca nie wprowadził terminologicznego rozróżnienia, które pozwalałoby stwierdzić, jakie narzędzie planistyczne jest preferowane dla obszaru o określonej powierzchni.

Co więcej, ustawodawca nie wprowadził wymagań ani dyrektyw co do wielkości obszaru, który powinien być obejmowany danym planem miejscowym - nie wskazał powierzchni minimalnej ani maksymalnej. Lektura u.p.z.p. może więc doprowadzić do wniosku, że wielkość obszaru obejmowanego planem miejscowym zależy w istocie od uznania danej gminy, uprawnionej w świetle art. 3 ust. 1 u.p.z.p. do kształtowania i prowadzenia polityki przestrzennej na swoim terenie.

Niemniej w przypadku ograniczenia badania zagadnienia jedynie do lektury przepisów u.p.z.p. pod kątem wyrażonej explicite dopuszczalności uchwalenia mikroplanu (np. w celu zrekonstruowania normy wskazującej na minimalną bądź maksymalną wielkość obszaru, jaki może zostać objęty danym planem miejscowym) nie będzie możliwe należyte ustalenie odpowiedzi na pytanie zadane na początku opracowania. Należy bowiem zwrócić uwagę na szczególną konstrukcję tej ustawy - oprócz przepisów dotyczących praw i obowiązków organów oraz procedury planistycznej istotną rolę pełnią początkowe przepisy u.p.z.p. Wydaje się więc, że dopiero ich pogłębiona analiza może doprowadzić do znalezienia poprawnej odpowiedzi na pytanie postawione w niniejszym artykule.

\section{Mikroplan wobec ładu przestrzennego oraz władztwa planistycznego gminy}

Z faktu, że przepisy u.p.z.p. wprost nie zabraniają uchwalania planu miejscowego dla niewielkiego obszaru, składającego się np. z jednej nieruchomości, nie można wywieść, że system planowania i zagospodarowania przestrzennego akceptuje w pełni taką działalność planistyczną. $Z$ tego względu, aby uzyskać odpowiedź na pytanie zadane na początku opracowania, konieczne jest zbadanie, czy koncepcja mikroplanu odpowiada war- 
tościom stanowiącym fundament przepisów z zakresu planowania i zagospodarowania przestrzennego.

Należy zwrócić uwagę, że przepisy art. 1 i art. 2 u.p.z.p. są kluczowe dla odtworzenia wskazań ustawodawcy co do treści planu miejscowego. Zgodnie $z$ art. 1 ust. 1 u.p.z.p. „Ustawa określa: 1) zasady kształtowania polityki przestrzennej przez jednostki samorządu terytorialnego i organy administracji rządowej, 2) zakres i sposoby postępowania w sprawach przeznaczania terenów na określone cele oraz ustalania zasad ich zagospodarowania i zabudowy - przyjmując ład przestrzenny i zrównoważony rozwój za podstawę tych działań”. Z kolei art. 1 ust. 2 u.p.z.p. stanowi, że „W planowaniu i zagospodarowaniu przestrzennym uwzględnia się zwłaszcza: 1) wymagania ładu przestrzennego, w tym urbanistyki i architektury [...]". Zatem przepis art. 1 ust. 1 i ust. 2 u.p.z.p., poza wskazaniem materii regulowanej przez ustawę (przedmiotu ustawy) ${ }^{24}$, wprowadza również zasady kształtowania polityki przestrzennej w postaci m.in. ładu przestrzennego, co ujmowane jest jako włączenie do przedmiotu ustawy takich zagadnień, jak „wartości i merytoryczne wymogi, które organy muszą uwzględnić, prowadząc ustawową działalność”25. Co więcej, przepisy te „stanowią [...] właśnie katalog zasad obowiązujących organ w zakresie kształtowania polityki przestrzennej. Uwzględnienie powyższych zasad jest więc warunkiem uznania aktu planistycznego za podjęty zgodnie z przepisami”26. Ustawodawca podjął próbę zdefiniowania pojęcia ładu przestrzennego, wskazując, że jest to „takie ukształtowanie przestrzeni, które tworzy harmonijną całość oraz uwzględnia w uporządkowanych relacjach wszelkie uwarunkowania i wymagania funkcjonalne, społeczno-gospodarcze, środowiskowe, kulturowe oraz kompozycyjno-estetyczne" (art. 2 pkt 1 u.p.z.p.). Idąc dalej, zasady ochrony i kształtowania ładu przestrzennego stanowią element, który obowiązkowo powinien zostać określony w miejscowym planie (art. 15 ust. 2 pkt 2 u.p.z.p.).

Warto zwrócić uwagę, że istota pojęcia ładu przestrzennego w świetle ukształtowanej przez ustawodawcę definicji ogniskuje się w następującym fragmencie: „takie ukształtowanie przestrzeni, które tworzy harmonijną całośc”. Istotą ładu przestrzennego jest więc spójne, harmonijne kształtowanie przestrzeni, zgodnie z wypracowaną wcześniej koncepcją, która ma zostać utrwalona w miejscowym planie, a następnie - na jego podstawie wdrożona. Osiągnięcie stanu „harmonijnej całości” wobec danej przestrzeni może być efektem jedynie wypracowania optymalnych współzależności na danym terenie pomiędzy warunkami i wymaganiami funkcjonalnymi, społeczno-gospodarczymi, środowiskowymi, kulturowymi oraz kompozycyjno-estetycznymi. Koncepcja opracowana przez

24 Z. Niewiadomski, Komentarz do art. 1, [w:] Planowanie i zagospodarowanie przestrzenne. Komentarz, red. Z. Niewiadomski, Legalis/el. 2015, Nb. 2.

25 Ibidem, Nb. 5.

26 Ibidem. Cf. A. Plucińska-Filipowicz, T. Filipowicz, Komentarz do art. 1, [w:] Ustawa o planowaniu..., op. cit., Nb. 9. 
organy planistyczne, a utrwalona w planie miejscowym, powinna więc odzwierciedlać ukształtowany, wyważony model wzajemnego oddziaływania pomiędzy powyższymi czynnikami ${ }^{27}$.

Można więc założyć, że ustawodawca, nakazując wprowadzenie w miejscowym planie zasad ochrony i kształtowania przestrzeni w sposób tworzący harmonijną całość, z uwzględnieniem wielu czynników wymienionych w art. 1 ust. 2 u.p.z.p., nakazał wyodrębnienie pewnego fragmentu z przestrzeni leżącej w granicach gminy, który powinien być w spójny sposób ukształtowany, tak by docelowo powstała w jego ramach „harmonijna całość”. Jednocześnie wyodrębniony z przestrzeni teren, który ma zostać objęty planem miejscowym, powinien dać możliwość uwzględnienia tych uwarunkowań, o których mowa w art. 1 ust. 2 u.p.z.p. Powstaje więc pytanie, czy mikroplan, traktujący przestrzeń jedynie w sposób wycinkowy, jest w stanie spełnić wymogi związane z zasadą ładu przestrzennego, a w szczególności czy docelowo umożliwi utworzenie na danym obszarze „harmonijnej całości”. Ze względu na wielość uwarunkowań, jakie powinno spełnić dane ukształtowanie przestrzeni, wymienionych w ustawowej definicji ładu przestrzennego (,wszelkie uwarunkowania i wymagania funkcjonalne, społeczno-gospodarcze, środowiskowe, kulturowe oraz kompozycyjno-estetyczne" - art. 2 pkt 1 u.p.z.p.), nie wydaje się, aby ich realizacja mogła nastąpić wyłącznie w ramach jednej nieruchomości. Opracowanie spójnej koncepcji optymalnego ukształtowania zagospodarowania danego terenu wymaga spojrzenia na szerszy obszar aniżeli jedna nieruchomość - i wydaje się, że z takiego właśnie założenia wyszedł ustawodawca, tworząc plan miejscowy jako akt prawa miejscowego; nie przewidywał on bowiem przyjęcia takiego planu dla jednej nieruchomości.

Przechodząc do zagadnienia władztwa planistycznego, trzeba stwierdzić, że to właśnie gminie przysługuje ustawowa kompetencja dotycząca władczego przeznaczania i ustalania zasad zagospodarowania terenu w drodze wiążącego aktu prawnego, w analizowanej sytuacji - miejscowego planu ${ }^{28}$. Władztwo planistyczne stanowi jeden z rodzajów władztwa administracyjnego, określanego jako uprawnienie „organu administracji publicznej do wiążącej konkretyzacji praw i obowiązków adresata, których wykonywanie, w sytuacji gdy treścią tej konkretyzacji było nałożenie obowiązków, obwarowane jest możliwością zastosowania środków przymusu państwowego" ${ }^{29}$. Podobnie według W. Jakimowicza władztwo planistyczne jest silnie powiązane z władztwem publicznym, wynikającym z kolei z samodzielności gminy, która jest określana przez jej prawa i obo-

27 M. Tabernacka, Konflikty dotyczace interpretacji pojęcia „tad przestrzenny” w planowaniu $i$ zagospodarowaniu przestrzennym, [w:] Ptaszczyzny konfliktów w administracji publicznej, red. M. Tabernacka, R. Raszewska-Skałecka, Warszawa 2010, s. 404.

28 Z. Niewiadomski, Komentarz do art. 3, [w:] Planowanie i zagospodarowanie..., op. cit., Nb. 1.

29 Z. Niewiadomski, Planowanie przestrzenne..., op. cit., s. 90-91. 
wiązki publicznoprawne ${ }^{30}$. Natomiast względem władztwa administracyjnego władztwo planistyczne określane jest jako jego rodzaj, zawężony „przedmiotowo do planowania przestrzennego" ${ }^{31}$.

Pomimo tego, że władztwo planistyczne gminy stanowi uprawnienie do „legalnej ingerencji w sferę wykonywania prawa własności”32, nie może być ono utożsamiane z przyznaniem „władztwa absolutnego i nieograniczonego, gdyż gmina, wykonując je, ma obowiązek działać w granicach prawa, kierować się interesem publicznym, wyważać interesy publiczne $\mathrm{z}$ interesami prywatnymi, uwzględniać aspekt racjonalnego działania i proporcjonalności ingerencji w sferę wykonywania prawa własności"33. Uprawnienie przyznane gminie nie jest absolutne; $z$ tego też względu, nie jest wykluczone w danym stanie faktycznym nadużycie władztwa planistycznego, które określane jest jako brak „właściwego wyważenia kolidujących wartości, które muszą być uwzględnione w planowaniu i zagospodarowaniu przestrzennym" ${ }^{34}$.

Należy zwrócić uwagę, że prawidłowe uwzględnienie ładu przestrzennego decyduje o należytym wykonaniu władztwa planistycznego. Ład przestrzenny wraz ze zrównoważonym rozwojem tworzą wzorzec umożliwiający kontrolę konkretnych rozwiązań planistycznych, przyjętych w ramach planu miejscowego. Jak mówi K. Buczyński, zasady ładu przestrzennego oraz zrównoważonego rozwoju stają się „głównymi miernikami prawidłowości i legalności realizacji przepisów komentowanej ustawy [tj. u.p.z.p. - D.I.]. Zgodność danego przedsięwzięcia planistycznego z obowiązującym porządkiem prawnym będzie ustalana po jego skonfrontowaniu $z$ wymogami ładu przestrzennego [...]" ${ }^{35}$. Jeżeli więc gmina podejmuje działania planistyczne związane z przyjęciem miejscowego planu w zakresie obszaru, którego powierzchnia jest zbyt mała, aby możliwe było uwzględnienie wszystkich zależności wskazanych przez u.p.z.p., istnieje ryzyko, że gmina nadużyła władztwa planistycznego.

Niemniej istotny jest także aspekt proceduralny uchwalania mikroplanu - mimo że jest on przyjmowany dla niewielkiego obszaru, konieczne jest przeprowadzenie pełnego postępowania planistycznego zgodnie $z$ regulacją u.p.z.p. Wnosząc ze sposobu ukształtowania obowiązków organów planistycznych w tym zakresie oraz konieczności zaan-

30 W. Jakimowicz, O normatywnych podstawach władztwa planistycznego gminy, [w:] Kierunki reformy prawa planowania i zagospodarowania przestrzennego, red. I. Zachariasz, Warszawa 2012, Nb. 2.

31 Ibidem.

32 J. Parchomiuk, Nadu̇ycie wtadztwa planistycznego gminy, „Samorząd Terytorialny” 2014, nr 4, s. 23.

33 Ibidem.

34 Ibidem, s. 30.

35 K. Buczyński, Komentarz do art. 1, [w:] Ustawa o planowaniu i zagospodarowaniu przestrzennym. Komentarz, Warszawa 2014, Nb. 3; wyrok WSA w Bydgoszczy z dnia 20 grudnia 2006 r., sygn. akt II SA/Bd 341/06. 
gażowania wielu organów wydaje się, że procedura została ukształtowana na potrzeby prac planistycznych obejmujących większy obszar aniżeli jedna nieruchomość (art. 17 u.p.z.p.).

W przypadku mikroplanu szczególnie przedstawia się sytuacja właściciela nieruchomości nim objętego. Procedura przyjęcia miejscowego planu nie przyznaje bowiem właścicielom nieruchomości, które mają być objęte planem, wyraźnych uprawnień w zakresie kształtowania ustaleń przyszłego planu miejscowego. Właścicielom nie przyznano uprawnień innych niż jakimkolwiek podmiotom zainteresowanym. W świetle u.p.z.p. właściciel może zatem: złożyć wniosek do planu miejscowego (art. 17 pkt 1 u.p.z.p.); wnieść uwagi do projektu planu miejscowego (art. 18 u.p.z.p.); wziąć udział w dyskusji publicznej nad projektem planu (art. 17 pkt 9 u.p.z.p.). Jednak wskazane wyżej środki nie wywierają istotnego wpływu na ustalenia zawarte w planie miejscowym, a rozstrzygnięcia co do ich uwzględnienia bądź odmowy uwzględnienia nie podlegają zaskarżeniu do sądu administracyjnego (art. 7 u.p.z.p.). Dopiero post factum właściciel nieruchomości objętej mikroplanem jest władny spowodować wszczęcie kontroli sądu administracyjnego nad wprowadzonymi w mikroplanie rozwiązaniami w trybie określonym w ustawie o samorządzie gminnym. Jednakże - biorąc pod uwagę, że skarga do sądu administracyjnego może zostać złożona dopiero po uchwaleniu planu - z punktu widzenia właściciela uprawnienie to może mieć charakter iluzoryczny, gdyż nie przyznaje mu kompetencji do udziału w kształtowaniu treści ustaleń, które dopiero w przyszłości mają być zawarte w mikroplanie.

Dla porównania warto zwrócić uwagę na przebieg postępowania o wydanie decyzji o warunkach zabudowy, która najczęściej odnosi się do sposobu zagospodarowania terenu składającego się z jednej nieruchomości. $\mathrm{W}$ tym przypadku podmiotem, który decyduje o wszczęciu postępowania, jest inwestor zainteresowany zmianą zagospodarowania terenu. Jednocześnie decyzja ta jest wydawana po przeprowadzeniu postępowania administracyjnego, w związku z czym wnioskodawcy przysługują wszelkie uprawnienia związane z kontrolą rozstrzygnięcia, zarówno przez organ odwoławczy, jak i sąd administracyjny. Podobnie kształtuje się sytuacja właścicieli nieruchomości sąsiadujących z nieruchomością, która ma być objęta mikroplanem. W ramach procedury planistycznej nie mają oni rzeczywistego wpływu na ustalenia, które będą dotyczyły sąsiadującej działki. Aktualne pozostaje również pytanie, czy są oni podmiotami uprawnionymi do złożenia skargi do sądu administracyjnego, skoro ich nieruchomość nie jest objęta mikroplanem? (Kwestię tę poruszono w orzecznictwie Naczelnego Sądu Administracyjnego, o czym niżej.) Natomiast w ramach postępowania o wydanie decyzji o warunkach zabudowy jego stronami są również właściciele lub użytkownicy wieczyści działek sąsiednich ${ }^{36}$, jak i działek niesąsiadujących bezpośrednio z terenem, na którym planowana jest inwesty-

36 Wyrok NSA z dnia 3 lutego 2011 r., sygn. akt II OSK 206/10 
$\mathrm{cja}^{37}$. Podmioty te są więc uprawnione do aktywnego udziału w postępowaniu, korzystania ze środków odwoławczych, jak i zaskarżenia decyzji organu odwoławczego do sądu administracyjnego.

$\mathrm{Na}$ tym tle sięganie przez organy planistyczne do mikroplanów stwarza ryzykowną sytuację dla uprawnień właścicieli. Kwestia ta jest kluczowa dla oceny badanego zagadnienia, skoro w świetle art. 6 ust. 1 u.p.z.p. ustalenia miejscowego planu kształtują sposób wykonywania prawa własności nieruchomości. Odmienny kształt procedur w sprawie przyjęcia mikroplanu oraz wydania decyzji o warunkach zabudowy sugeruje, że mikroplan - z perspektywy gminy - może w istocie w danych okolicznościach faktycznych stanowić środek zamienny względem decyzji o warunkach zabudowy. W zakresie skutków mikroplanu funkcjonalnie jest on zbliżony do indywidualnego aktu stosowania prawa, teoretycznie mając wszystkie cechy właściwe dla planu miejscowego.

W związku z tym istnieje ryzyko, że w określonym stanie faktycznym przyjęcie mikroplanu może stanowić nadużycie władztwa planistycznego gminy. Nadużycie takie może przejawić się na kilku płaszczyznach. Po pierwsze, może wiązać się z nienależytym uwzględnieniem dyrektyw wynikających z konieczności zachowania ładu przestrzennego. Po drugie, może wiązać się z niewłaściwym wyważeniem kolidujących wartości, $\mathrm{w}$ postaci interesu publicznego oraz prawa własności - wydaje się, że często w przypadku uchwalenia mikroplanu nieuzasadnioną przewage uzyska jedna $z$ tych wartości. Po trzecie, co jest powiązane $z$ dwoma wymienionymi wyżej, może przejawić się na płaszczyźnie proceduralnej. Uchwalenie mikroplanu jest bowiem skutkiem skomplikowanej procedury planistycznej, którą ustawodawca, jak się wydaje, przewidział dla większych obszarów. Ponadto, mając na uwadze to, że często bezpośrednim celem gminy jest ukształtowanie sposobu zagospodarowania danej, konkretnej nieruchomości, uchwalenie mikroplanu może doprowadzić, po pierwsze, do znacznego pogorszenia sytuacji prawnej właściciela tej nieruchomości, któremu nie przysługują efektywne środki prawne w celu zweryfikowania poprawności działań organu planistycznego; po drugie, ustalenia zawarte w mikroplanie mogą w nieuzasadniony sposób polepszać sytuację prawną właściciela, np. wprowadzając ustalenia korzystne dla niego, choć kolidujące $z$ interesem właścicieli nieruchomości sąsiednich, którym również nie będą przysługiwały żadne skuteczne instrumenty umożliwiające kontrolę legalności ustaleń mikroplanu.

\section{Mikroplan w orzeczeniach sądów administracyjnych}

Tematyka mikroplanu nie jest szeroko poruszana w orzeczeniach sądów administracyjnych. Jeżeli zagadnienie mikroplanu jest rozważane przez sąd, to raczej w kontekście realiów danego stanu faktycznego, a nie założeń teoretycznych, czy zasad rządzących

37 Wyrok NSA z dnia 8 września 2004 r., sygn. akt OSK 394/04. 
planowaniem przestrzennym. Przykładowo, Wojewódzki Sąd Administracyjny w Warszawie w orzeczeniu z 2010 r. stwierdził, że „przepisy ustawy o planowaniu i zagospodarowaniu przestrzennym nie zabraniają objęcia ustaleniami planu niewielkiego obszaru, w tym także uchwalania planu dla jednej działki ewidencyjnej"38. Natomiast Wojewódzki Sąd Administracyjny w Gdańsku w 2011 r. zauważył, że dopuszczalne jest uchwalenie planu miejscowego tylko dla jednej nieruchomości, a może to być uzasadnione jej przeznaczeniem na cele publiczne; jednak, wobec braku możliwości porównania do sytuacji prawnej właścicieli innych nieruchomości konieczne jest gruntowne uzasadnienie takiego działania. Sąd zwrócił także uwagę na to, że uchwalenie planu miejscowego dla jednej nieruchomości w drodze kosztownej i czasochłonnej procedury planistycznej powinno mieć uzasadnienie, zwłaszcza że co do zasady możliwość zagospodarowania terenu w sposób zapewniający ład przestrzenny na terenie jednej nieruchomości następuje przez wydanie decyzji o warunkach zabudowy ${ }^{39}$.

Do zagadnienia mikroplanu odniósł się także Naczelny Sąd Administracyjny, wskazując, że:

[mikroplan - D.I.] w aspekcie praktycznym niewiele różni się od wydania decyzji o ustaleniu warunków zabudowy. [...] uchwalenie planu dla jednej tylko działki ma takie konsekwencje, że jej właściciel będzie mógł realizować swoje zamierzenia inwestycyjne bez konieczności wcześniejszego ustalenia w postępowaniu administracyjnym warunków zabudowy dla inwestycji, na etapie którego m.in. właściciele działek sąsiadujących z planowaną inwestycją posiadają uprawnienie do ochrony ich interesu prawnego przy zabudowie nienależących do nich terenów [...].

W orzeczeniu tym Sąd nie kwestionował samej możliwości uchwalenia mikroplanu, ale dostrzegł podobieństwo istoty mikroplanu do decyzji o warunkach zabudowy, i to pomimo braku szerszych uprawnień dla podmiotów, na których sytuację prawną wpływają ustalenia zawarte w mikroplanie. W konsekwencji dopuścił możliwość zaskarżenia mikroplanu przez właścicieli nieruchomości sąsiadujących z obszarem nim objętym, wskazując, że mają oni jak najbardziej interes prawny w zaskarżeniu uchwały w sprawie mikroplanu ${ }^{40}$.

W 2015 r. w zakresie dopuszczalności mikroplanów wypowiedział się Wojewódzki Sąd Administracyjny w Poznaniu, wskazując, że „było dopuszczalnym prawnie i co za tym idzie nie stanowiło naruszenia granic władztwa planistycznego przysługującego

38 Wyrok WSA w Warszawie z dnia 5 lutego 2010 r., sygn. akt VII SA/Wa 2076/09.

39 Wyrok WSA w Gdańsku z dnia 12 października 2011 r., sygn. akt II SA/Gd 265/11.

40 Wyrok NSA z dnia 13 grudnia 2012 r., sygn. akt II OSK 2273/11. 
gminie, uchwalenie planu miejscowego obejmującego jedynie jedną działkę gruntu, należącą do skarżącego [...]" ${ }^{\prime \prime 1}$.

Wynika z tego, że sądy administracyjne zdają się w sposób bardzo ostrożny akceptować praktykę uchwalania mikroplanów, wskazując jednak, po pierwsze, na konieczność wyczerpującego uzasadnienia, dlaczego takie rozwiązanie stało się nieodzowne, a po drugie, na obowiązek efektywnej ochrony praw podmiotów innych niż właściciele nieruchomości objętych planem, których sytuację prawną mogą w określonym zakresie kształtować ustalenia mikroplanu. Wydaje się jednak, że konieczna jest pogłębiona analiza zagadnienia mikroplanu także w orzecznictwie sądów administracyjnych, zwłaszcza w kontekście ładu przestrzennego oraz obowiązku należytego wykonywania władztwa planistycznego.

\section{Mikroplan jako sygnał konieczności wprowadzenia nowych rozwiązań?}

Należy wskazać, że mikroplan w wyraźny sposób uwypukla wady obecnego systemu planowania i zagospodarowania przestrzennego. $Z$ jednej strony koncepcja mikroplanu jest spójna z prezentowanymi zapatrywaniami na charakter prawny planu miejscowego. Co więcej, trudno zidentyfikować przepis, który wprost stanowiłby o niedopuszczalności przyjęcia planu miejscowego dla niewielkiego obszaru. $Z$ drugiej strony pogłębiona interpretacja zasad planowania i zagospodarowania przestrzennego zdaje się wskazywać, że praktyka uchwalania mikroplanów nie jest w pełni zgodna z prawem. Mikroplan staje się bowiem narzędziem - zachowującym co prawda charakter prawny planu miejscowego - funkcjonalnie odpowiadającym indywidualnemu aktowi administracyjnemu, służącym do uregulowania sytuacji prawnej konkretnego podmiotu, będącego właścicielem nieruchomości objętej mikroplanem. Przedmiotem regulacji mikroplanu jest nadal sposób zagospodarowania danej przestrzeni, lecz nie jest to cel, dla którego gmina go przyjmuje. Wydaje się, że funkcją mikroplanu jest bezpośrednio kształtowanie uprawnień w zakresie zagospodarowania działki, przysługujących konkretnemu podmiotowi. Nie ulega wątpliwości, że skutkiem akceptacji takiego schematu działania jest instrumentalizacja planu miejscowego.

Powyższe zjawisko sygnalizuje, że procedura planistyczna w obecnym kształcie jest zbyt mało elastyczna i nie pozwala na kompleksowe ujęcie występujących na danym obszarze problemów. Praktyka uchwalania mikroplanów pokazuje, że konieczna jest dogłębna refleksja na temat nowych rozwiązań, które sprawią, że plan miejscowy - najistotniejszy element polskiego systemu planowania przestrzennego - będzie należycie

41 Wyrok WSA w Poznaniu z dnia 6 lutego 2015 r., sygn. akt II SA/Po 1278/14; orzeczenie nie jest prawomocne. 
276 | Adam Mickiewicz University Law Review

wypełniał swoją rolę, nie podlegając instrumentalizacji w celu rozwiązania doraźnych problemów.

\section{Literatura}

Brzeziński W., Plan zagospodarowania przestrzennego. Studium z zakresu nauki administracji i prawa administracyjnego, Warszawa 1961.

Buczyński K., Komentarz do art. 1, [w:] Ustawa o planowaniu i zagospodarowaniu przestrzennym. Komentarz, LexisNexis/el. 2014.

Jakimowicz W., O normatywnych podstawach wtadztwa planistycznego gminy, [w:] Kierunki reformy prawa planowania i zagospodarowania przestrzennego, red. I. Zachariasz, Warszawa 2012.

Kulesza M., Administracyjnoprawne uwarunkowania polityki przestrzennej, Warszawa 1987.

Leoński Z., Szewczyk M., Kruś M., Prawo zagospodarowania przestrzeni, Warszawa 2012.

Longchamps F., O pojęciu stosunku administracyjnoprawnego w gospodarce narodowej, „Państwo i Prawo”1958, nr 1.

Malinowski R., Ewolucja systemu planowania gospodarczego a problem charakteru prawnego planów gospodarczych, „Państwo i Prawo” 1975, nr 2.

Niewiadomski Z., Planowanie przestrzenne. Zarys systemu, Warszawa 2003.

Parchomiuk J., Nadużycie wtadztwa planistycznego gminy, „Samorząd Terytorialny” 2014, nr 4.

Planowanie i zagospodarowanie przestrzenne. Komentarz, red. Z. Niewiadomski, Legalis/ el. 2015.

Plucińska-FilipowiczA.,FilipowiczT., Komentarzdo art. 4, [w:] Ustawa oplanowaniuizagospodarowaniu przestrzennym. Komentarz, red. A. Plucińska-Filipowicz, M. Wierzbowski, LEX/el. 2014.

Tabernacka M., Konflikty dotyczqce interpretacji pojęcia „tad przestrzenny” w planowaniu i zagospodarowaniu przestrzennym, w: Ptaszczyzny konfliktów w administracji publicznej, red. M. Tabernacka, R. Raszewska-Skałecka, Warszawa 2010.

\section{SUMMARY}

\section{A microplan of spatial development - analysis of chosen aspects}

The article examines a new tendency in the Polish system of local spatial planning and development, i.e. the microplan of spatial development. The aim of the work is to verify whether the above-mentioned tendency is entirely compliant with the rules expressed by 
the lawgiver in the Act on spatial planning and development, as well as the basic principle of the planning activities - spatial order. Furthermore, the author focuses on the theoretical views on the construction of a local spatial development plan in the context of a microplan. The analysis also includes the relation between the above-mentioned tendency and the rules governing the planning of self-governance as the entitlement exercised by the municipality.

Keywords: local spatial development plan, "microplan" of spatial development, individual act of multiple application, local law, spatial order, planning self-governance

Diana ILków, The Institute of Law Studies of the Polish Academy of Sciences, Nowy Świat 72, 00-330 Warsaw, e-mail: dianailkow@wp.pl. 